\title{
Co-evolution of Technical and Social Change in Action: Hasselt's Approach to Urban Mobility
}

\author{
RALF BRAND
}

\begin{abstract}
Much contemporary sustainability policy is a mix of a little bit of technological fix and a little bit of social campaigning. But this seemingly fair compromise misses important potentials for concrete progress towards a more sustainable society. What is needed instead is a synergistic, strategically synchronized or co-evolutionary relationship between technical and social change. The mobility policy in the Belgian city of Hasselt, presented as the empirical core of this paper, provides support for this position. Its underlying principle is the attempt to make more sustainable behaviours attractive through a coherent set of policy, social and urban design interventions. What makes this case successful is not just its massive scale but the synergistic coherence of all measures. Hasselt is therefore a case from which mobility experts - technophiles and technophobes alike - can learn.
\end{abstract}

The discourse on sustainable development - including that on sustainable mobility - is quite often framed in an unfortunate, dichotomous way, couched between technological utopianism on the one hand and calls for behavioural changes on the other. Champions of the former argue that technological interventions will solve most (environmental) aspects of the sustainability challenge without requiring any compliance by allegedly unreliable human users. According to the latter disposition, sustainable development can only be achieved if we radically change our consumptive lifestyles. From this perspective, any form of technological intervention will only nurture the illusionary hope that we can evade collapse without making radical social changes.

Many other practitioners and scholars detect cognate manifestations of essentially the same 'discourse structure' (Hajer, 1996). Among them are Job (1995) who sees technocentric and ecocentric perspectives as the two ends of the sustainability spectrum, Thayer (1994) who considers technophilia and technophobia as the constituting elements of the environmental debate or Ravetz (2001) who distinguishes between a technological scenario and a deep ecology scenario. O'Riordan (1989) detects a dichotomy between anthropocentrism and ecocentrism and similarly Robinson (2004) clusters the plethora of suggestions into the two archetypal categories of technical fix versus value change. Robinson also links the structure of the contemporary sustainability discourse to the 'argument between Paul Ehrlich and Barry Commoner ... about the relative importance of technology and individual human responsibility that has been an abiding theme in the [sustainability] literature since the early 1970s' (Ibid., 2004, p. 371). Although not exactly parallel to this discourse it nevertheless resonates closely with the long-standing debate about strong versus weak sustainability. 
Observers of contemporary politics will find it easy to confirm these scholarly analyses. The US President, for example, declared that 'the best way to break this addiction [to oil] is through technology' (BBC, 2006). A recent report for the UK Department of Transport focused exclusively on ways to catalyse travel behaviour change (Anable et al., 2006). Also the extremely influential 'Stern Review' (Stern, 2007) employs a rather dichotomous rhetoric by recommending efficient technology and behavioural change - apart from carbon pricing. For the economist Nicholas Stern and his readers it is primarily money that is at stake; for many scholars it is truth itself. Jepson $(2004$, p. 13) thus observes that the 'positioning of sustainable development between two worldviews makes it ... particularly prone to "wildly different conclusions" and the holding of views with extreme "rigidity'". A rather unfortunate situation as I intend to demonstrate below.

Of course, not all sustainability strategies occupy the extreme ends of this spectrum. Many contemporary sustainability policies fall into the middle ground with a little bit of technical fix and a little bit of social campaigning. On close, empirical examination, however, even such a seemingly fair compromise misses important potentials for concrete progress towards a more sustainable society. This paper contains evidence that aspirations beyond such an additive logic are justified and that it is not only possible but crucial to pursue a synergistic, strategically synchronized or co-evolutionary relationship between technical innovation (e.g. infrastructure, buildings, machines, etc.) and social change (e.g. habits, preferences, behaviours, etc.).

The case in point is the mobility policy of the Belgian city of Hasselt which used to suffer from severe traffic related problems such as accidents, traffic congestion, air pollution, low mobility for senior citizens, poor accessibility of the city centre etc. Initially, the proposed solutions ranged from building a third ring road in order to divert traffic from the city centre (technical fix) to persuading citizens to use alternative modes of transport through a concerted awareness campaign (behaviour fix). In the end, however, the city council adopted neither of these strategies. Instead, it decided to make the built environment and other elements within its political remit more conducive to alternative forms of mobility through an integrated set of institutional, infrastructural and urban design interventions.

This paper is an abridged version of a more detailed description and assessment of these measures published elsewhere (Brand, 2005a). The empirical observations are followed by reflections on the descriptive and practical usefulness of the notion of a co-evolution between social and technical change. The final section presents a conceptual framework to help towards an understanding of the principles underlying co-evolutionary strategies and then proposes further research to advance the understanding and applicability of those principles.

\section{Empirical Observations in Hasselt}

Hasselt is the capital, commercial core and education centre of the province of Limburg in the eastern part of the Belgian region of Flanders (figure 1). Its population is close to 70,000 but it is effectively the service hub for all 800,000 citizens of Limburg which explains the massive traffic flows in and out of the city caused by 38,000 students who attend one of the many schools or one of the four colleges in Hasselt, the 46,000 employees and civil servants working in the city ${ }^{1}$ and the 164,000 customers who visit Hasselt's shops every week. Until the early 1990s, the city's public transport system was quite underdeveloped and car density was the highest in Flanders at 467 cars per 1000 inhabitants (Lambrechts, 2000a). Its inner ring road was the most dangerous road in the province, with over 30 accidents per kilometre annually (Stuurgroep Hasselt Levendig Stadscentrum, 1994, p. 15). 
Since the 1960s, Hasselt has also had an outer ring road which serves as a major arterial for through traffic as well as a distributor for traffic with destinations in Hasselt. Such was the situation in the early 1990s when several proposals were developed to solve Hasselt's traffic problems. Eventually, a new city government, elected in 1994, tackled the issue with a remarkably comprehensive mobility policy, whose key elements are described below.

\section{The Green Boulevard}

The Green Boulevard (figure 2) is certainly the most visible element of Hasselt's mobility policy. It is the result of a fundamental reconstruction of the inner ring road, which used to serve as a major traffic artery with two lanes in each direction. The two lanes in the clockwise direction were completely rededicated to other purposes. The outermost section is now a wide pavement, followed by a differently coloured bicycle lane. This is separated by a kerb from two lanes for motor vehicles, which allow only counterclockwise traffic at a maximum speed of 30 $\mathrm{km} / \mathrm{h}$. Differently coloured dedicated bus lanes along the south-western stretch of the Green Boulevard and at major intersections and bus stops ensure a smooth flow for public transport. Another kerb marks the outer edge of an 8 metre wide pedestrian

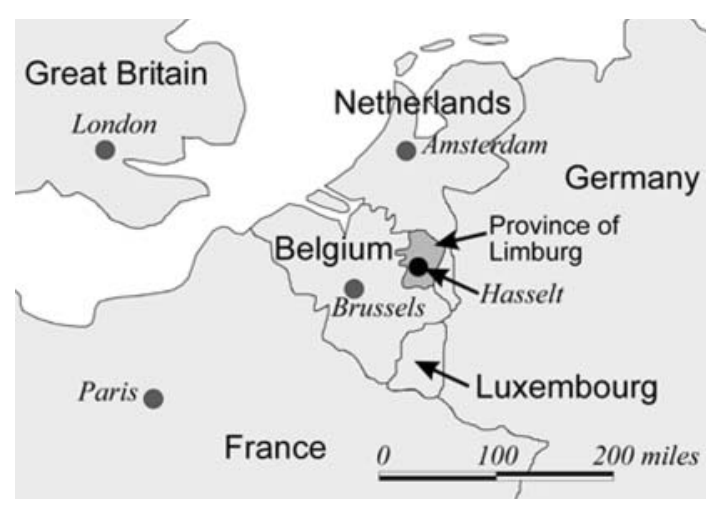

Figure 1. Map of Benelux countries, indicating the location of Hasselt. (Source: Ralf Brand) lane, which is lined with newly planted trees and street lights and furnished with benches and statues. Most of the Green Boulevard bus stations are located along this lane. Beyond the pedestrian lane there is a cobblestone lane, which allows slow traffic in a clockwise direction over short stretches only to destinations in the core of the city; it is also dedicated as a bicycle track. Immediately adjacent towards the inner edge of the boulevard is a cobbled parking lane, which can be used by short-term visitors using meters and without charge by residents whose cars have a sticker to authenticate their resident status. Finally, another pavement completes the Green Boulevard (figure 3).

\section{Radial Access Roads}

In order to divert through traffic from the inner ring road and to guide 'legitimate'

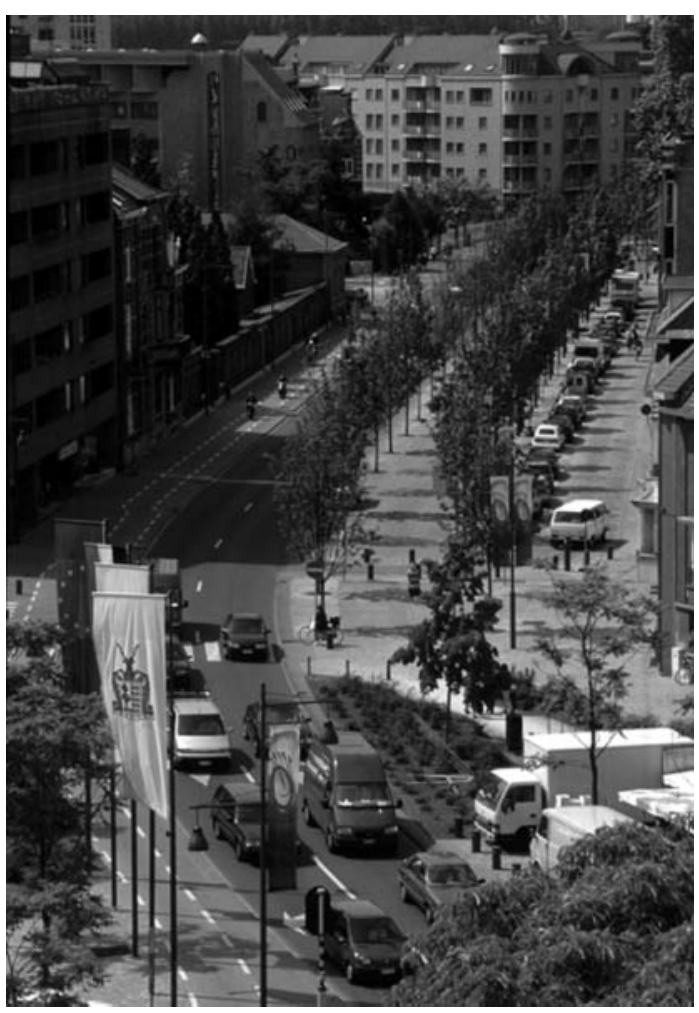

Figure 2. Angular view of the Green Boulevard. (Source: City of Hasselt, J. Jorissen) 


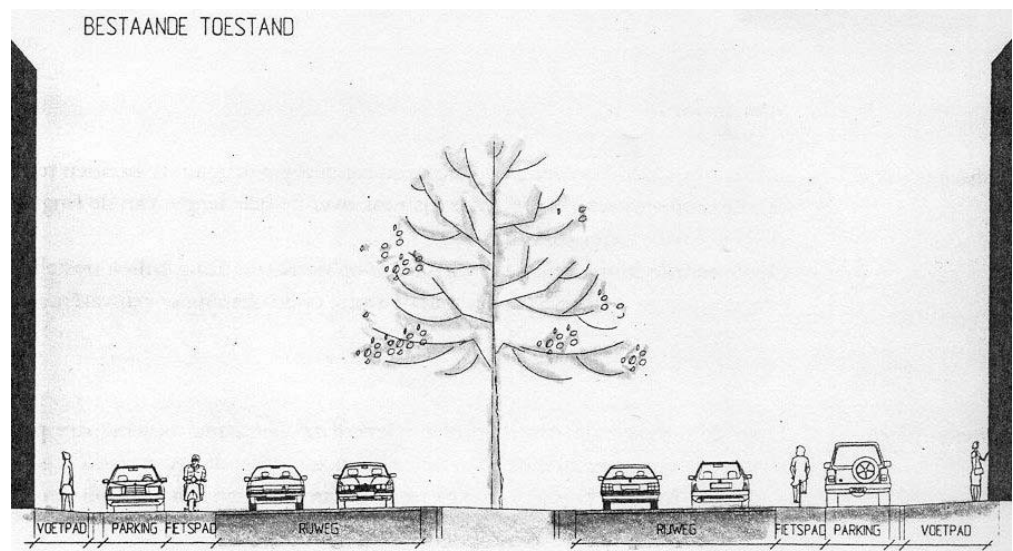

Figure 3. The inner ring road before (above) and after (below) the remodelling. (Source: Van Moerkerke, 1997, p. 103)

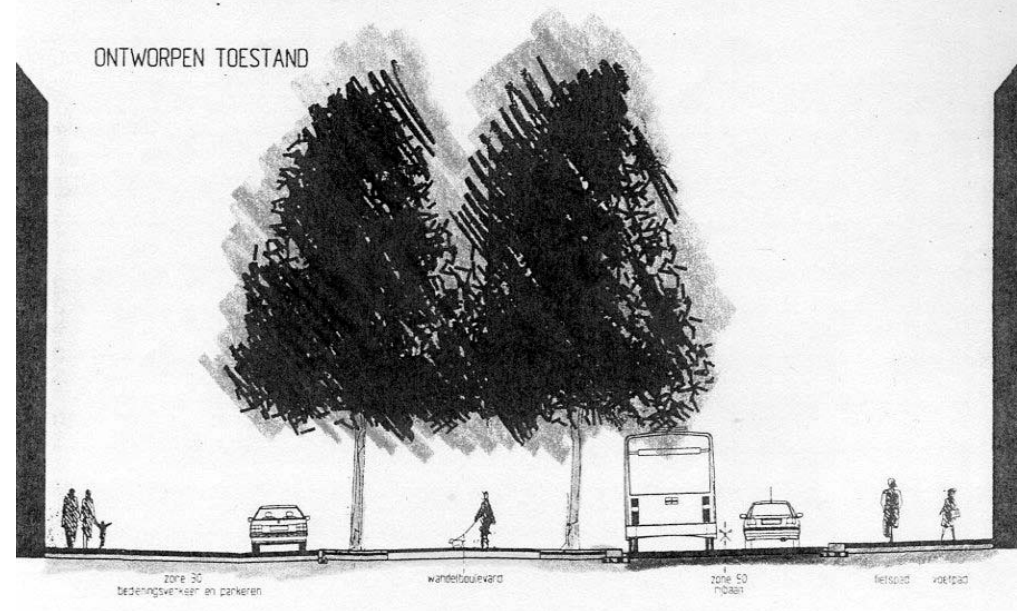

traffic to the least vulnerable roads, the city now employs a combination of informational and infrastructural strategies. New traffic signs help inter-regional traffic find its way along the outer ring road. For visitors, three main access roads are promoted as the main routes to parking facilities near the city centre. Few houses line these roads whereas housing along the other radial roads was intensified after thorough reconstruction: 'Car lanes were narrowed and the available free space added to pavements, cycle tracks and green areas' (MVGWV, 2001, p. 13). In addition, the speed limit on most of these roads was reduced to $30 \mathrm{~km} / \mathrm{h}$. The intended effect of these measures is to attract motorists along the three main access roads to parking places near the city centre, from which they can take the free and convenient buses (see below) to their final destination.

\section{Green Space and Living Space}

In the early 1990s, there were still extensive green spaces along the outer ring road, while green spaces in the inner city and green belts linking these two were scarce. The reconstruction and greening of the radial approach roads is thus an important link between the mobility and green-space policy. However, the most spectacular greenspace project in Hasselt is certainly the Green 
Boulevard, which got its name from the 450 trees and 'thousands of bushes' (Quintiens, n.d., p. 3) that were planted. Also worth mentioning are 420 Verkeerspaaltjes (antiparking poles), which were custom-made for Hasselt so that pedestrians can sit on them unlike their conventional spiky counterparts, which are constructed to discourage sitting. 'This is not a coincidence but well thought through' (Quintiens, n.d., p. 4), because the Green Boulevard is meant as space for human beings and not for cars.

\section{Mobility Hub}

The remodelling of the area around the train station into a public transport hub links several elements of Hasselt's mobility policy. Train users need parking spaces or good bus connections, visitors arriving by train need information about bus routes and schedules and users of the public transport system waiting for connections need restrooms and refreshments. Therefore, the train station's forecourt has been made optimally accessible for public transport, pedestrians, bicyclists, wheelchair-users and the visually impaired. Taxis and private cars can access the station square to drop off or pick up passengers. All bus routes converge at the station square, where displays at all seventeen bus bays provide real-time information about the expected arrivals. There is a bus company information centre in the middle of the square which provides heated shelter, maps of the bus network and schedules. A number of restaurants, pubs and concession stands have been renovated or opened around the area as a result of its greatly increased use.

As of December 2007, further work is underway to upgrade and redevelop the wider area into a 'railway station district'. This project will entail $60,400 \mathrm{~m}^{2}$ of floor space of which 28 per cent will be dedicated to residential use, 43 per cent to office space and the remainder to various other commercial uses. This mix is intended to further increase the attractiveness of inner- city live-and-work arrangements with minimal dependence on cars.

\section{Land-Use Policy}

The concept of the 'railway station district' is an example of Hasselt's general spatial planning strategy to densify land use, especially around public transport interchanges, in order to reduce the need for mobility through better availability of daily supplies at the neighbourhood-level (Lambrechts, 2001, p. 12) and to make public transport more viable. The decision, during its planning stage, to relocate the Vlaams Huis (a new administrative centre of the Flemish Community), closer to this mobility hub was part of this strategy because it enabled its 450 employees either to live nearby or to commute by train.

Another strategy is to reduce the number of empty houses in the inner city through negative tax incentives, with the aim of bringing life back to the centre. New developments must not be allowed along the outer ring road because this would induce more traffic and conflict with the city's green-space plan. This objective did not find unanimous support, however, especially not among potential investors such as Colruyt and Toys R Us. They wanted to build there and referred to building permits issued by the previous, Conservative city government, which were not upheld by the new SocialistGreen government.

The success of the Green Boulevard stimulated the ideas to create a 'Blue Boulevard' along a redundant industry canal. This area at the northern end of the core city with an envisaged total area of 450,000 $\mathrm{m}^{2}$ is currently (2007) being redeveloped into a mix of residential (67 per cent), office (23 per cent), retail ( 6 per cent) and other uses, again, to create a viable inner-city living environment.

\section{Public Transport Policy}

Public transport has been a poor relation in 
Hasselt for many decades, even according to an employee of the provincial public transport company (Buntinx, interview 26 November 2001). Since 1997, however, the city's public transport scheme has gained international attention because it is one of very few that is completely free of charge. The public transport policy, however, encompasses much more than just this monetary aspect. The 'number of buses has tripled' (Bormans, interview 26 November 2001) and their combined catchment area now reaches 96 per cent of Hasselt's population. Two bus routes are shuttle services, one along the inner ring road, running at five minute intervals, the other connecting the station and market square six times per hour. Three other routes are served every 15 minutes during peak hours and every 30 minutes at other times. Four more routes have half hourly services throughout the day. The new bus routes and schedules have been developed in consultation with Hasselt's companies to ensure that employees can use the buses to commute to work (MVGWV, 2001).

All routes combined are furnished with 270 bus stops, which is double the number of the old system. Many stops are protected with shelters; the three most frequented ones have 'pleasant, heated waiting rooms ... equipped with telephones, wash room facilities and a dynamic real-time information system' (Ibid.). This massive increase in service required a potent bus fleet, which was upgraded with 27 new vehicles. ${ }^{2}$ All are equipped with a kneeling system to make them accessible for elderly and disabled persons. Eighty-two bus drivers operate the bus fleet (before July 1997 there were only eighteen) and all 'received special training in public relations so that they could take care of the passengers instead of worrying about collecting fares' (Ibid., p. 29). Further plans exist to take this transport policy to the next level of ambition and scale: the Spartacusplan envisages Hasselt becoming the hub of a province-wide light-rail project which is supposed to be seamlessly linked to trains and express buses 'in order to convince people to make the switch from automobile to public transport' (Lambrechts, email 28 November 2007).

\section{Bicycle Policy}

Hasselt aims to ensure that the practical advantages - and not just environmental consciousness - stimulate the widespread use of bicycles, most prominently through a steep increase in bicycle lanes. All of the remodelled radial approach roads got a bicycle lane, the entire Green Boulevard has a bicycle lane on either side and major intersections were remodelled with an underpass for cyclists and pedestrians. To ensure that using a bicycle in the city is hassle-free, the city installed many bike racks and established four guarded bicycle sheds. Public agencies and some companies 'provide showers and cloakrooms next to the cycle sheds for their employees and workers who cycle to work' (MVGWV, 2001, p. 37).

School children are also encouraged and assisted to use their bikes through so-called Fietspools (bicycle pools), in which adults volunteer to guide children from their neighbourhood safely to school. The city provides safety jackets, promotional pennants, stickers and logistical and marketing support for this programme. Even for visitors it is now easy to use a bicycle in Hasselt, because bicycles, scooters and several non-motorized vehicles for people with special needs can be borrowed for a day free of charge from a depot behind the City Hall. Some of the bicycles are equipped with a child seat or a transport trailer.

\section{Pedestrian Policy}

The remodelling of the radial approach roads allowed the pavements to be widened. This, in combination with efforts to improve the availability of daily goods on the neighbourhood level, allows people to run many errands on foot (Lambrechts, 2001, p. 12). The aforementioned tunnels under major roads 
also supported this goal. The main focus for pedestrians, however, is dedicated to the shopping streets in the centre of the city, where access for cars is limited - controlled by means of retractable bollards - and where even cyclists and bus users usually become pedestrians. This pedestrianized area in the city centre will be doubled in 2008, which is considered 'a must for an enjoyable city' (Stad Hasselt, 2007b). Most people come there to shop, which is made less arduous through two parcel storage sites set up during special shopping seasons; local retailers co-sponsor this project for obvious reasons. Behind the City Hall, pedestrians with children can borrow buggies free (MVGWV, 2001, p. 37) and plans are under way to provide shopping carts which can be taken anywhere in the shopping district (Jacobs, 1996b). All of these measures are inspired by a declared will to 'make things safe and convenient for pedestrians' (Stad Hasselt, 2007b).

\section{Parking Policy}

The primary objective of the parking policy is to induce people to leave their cars outside the inner city and find their way to their final destination by bus, bicycle, or on foot. This presupposes not only good bus connections and bicycle sheds but also affordable and accessible parking facilities. Consequently, a number of parking sites were built next to the inner ring road. The parking policy also includes disincentives against parking inside the Green Boulevard. For this reason, the initial plans determined that 'the number of surface (paid) parking places [would be] halved in the city centre' (Anon., 1999, p. 5). While a number of parking spaces were indeed dismantled, some others were newly created on the inner side of the Green Boulevard. However, these are reserved for 'resident-parking and for quite expensive short-term parking' (MVGWV, 2001, p. 19). Another element of the parking policy is the parking guidance system, which leads visitors to strategically located parking facilities. Plans exist to upgrade this system to a remote-controlled, real-time information system. A more low-tech measure is a simple map showing the locations of all parking facilities, which is available free and distributed in particular to parking offenders (Jacobs, 1996a).

\section{Campaigns}

The technological/infrastructural changes described above were intended to facilitate behavioural changes. The direction of these desired changes was explicitly articulated through campaigns as integral elements of Hasselt's mobility policy. Hasselt graag traag (Slowly through Hasselt please) for example encourages motorists to drive slowly. The annual, Europe-wide Car-free Day is also promoted by the City of Hasselt with support from businesses, the Chamber of Commerce and schools (MVGWV, 2001, p. 37). The campaign Met Belgerinkel Naar De Winkel (Shopping with bicycle bells) includes a raffle with the chance to win a bicycle as first prize. Winners use alternative modes of transport - this is the message communicated widely in Hasselt. To support this claim, a race was arranged during a Week of Mobility between a car driver, pedestrian, bus user, skater and cyclist. The goal was to travel 3 kilometres through the city and to pick up the newly released mobility brochure at the City Hall. The results were widely communicated in the local media: The skater arrived first, followed shortly by the cyclist, who happened to be Mayor Stevaert. The car driver came in third but lamented paying $€ 2.23$ for parking. The bus user, who was the penultimate finisher, also had to pay $€ 1.56$ because the competition took place before the introduction of the new bus system. At that time, the inner ring was perceived as a road - full stop. Nowadays, it is made appealing as the Green Boulevard and personified through a friendly logo: a G-shaped arrow consisting of green leaves pointing in a counter-clockwise direction, with a smiley in the middle. 


\section{Results}

Comments on the effect of Hasselt's mobility policy range from enthusiastic to very contained. 'Following the obvious success of the project the scepticism disappeared' (Anon., 1999, p. 8) represents the former while an example of the latter is the statement 'Not everything the city does is wrong' (Lieshout, interview 27 November 2001). It should be kept in mind that the decisions made in Hasselt were never apolitical; neither are their effects and their perception. The appraisals thus should be considered in the context of the political interests of their authors: the enthusiastic quote above was made by an unnamed City Hall insider; the latter resonates the discontent with the marginalization of its author's right-wing party in the city parliament. Someone with no overt political interest, an academic traffic expert, admits that he would have preferred even more radical measures but he also points out: 'At least it is a step into the right direction ... and you can see that a city can become more beautiful, more pleasant and healthier' (Mulders, interview 30 June 2000).

A more detailed assessment would have to distinguish between different parameters like changes in the use of public transport, individual motorized traffic, the number of accidents, impacts on real estate prices, and even the effects on local pride or business climate. These and other issues are analysed in depth by Brand (2005a) but it makes sense also to summarize some key results here in order to justify any further preoccupation with this case. What appears sobering at first is Mulders's statement that 'we have not at all reached a point where the car comes second' (interview 30 June 2000). But at least, Heeren ascertains one month after the introduction of free public transport that 'the traffic pressure in Hasselt is already somewhat lower' (cited in Jacobs, 1997b, p. 1).

A quantitative analysis supports this claim to some extent. Calculations for January 1998 reveal that the new bus system alone helped avoid 28,529 trips through the city centre per month which corresponds to 950 trips per day or to one car per minute during the day (calculation in Brand, 2005a, p. 45). Apparently, the new one-way rule on the inner ring road caused some percentage of the overall traffic to shift to the outer ring road - much to the chagrin of some shopkeepers (Lijsweik, interview 27 November 2001). It also triggered some misdemeanours among motorists who might have missed their exit on the inner ring. Instead of completing another circulation of 2.36 miles they sometimes 'sneak 200 yards against the one-way direction during off-peak hours' (Meulendijk, interview 27 November 2001). The Conservative party is not completely happy with the one-way solution either, but they present constructive criticism for specific problematic spots. Quite unambiguous is the effect on the frequency and severity of traffic accidents. One author reports that 'collisions on the short ring road have been virtually reduced to nil' (Anon., 1999, p. 8).

'An absolute boom' is how Sabin S'Heeren, director of De Lijn Limburg, Limburg's public transport company, describes the effect of the free bus system (cited in Jacobs, 1997b, p. 1). Immediately after the buses were made free on 1 July 1997, 12,000 people per day used them compared to the previous average of 1,000 people (Jacobs, 2001, p. 1). Six months later, the local newspaper concluded that 'the first euphoria did not recede' (Jacobs, 1997d, p. 14) (figure 4). In the first year after the establishment of the new system, 2.7 million people made use of it, an increase by a factor of nine compared to the previous annual average (Bormans, interview 26 November 2001). The bus is the undisputed winner in the give-and-take relationship between all modes of transport. Of all bus users, 16 per cent had switched from cars, 12 per cent from bicycles and 9 per cent would have walked under the previous public transport system (Lambrechts, 2001, p. 5). This led Mulders to conclude that 'public transport turned from an underdog into a landmark in Hasselt 
Figure 4. Bus users per month from July 1996 to December 1999; plus monthly averages 2000 2006. (Source: Lambrechts, $2000 b$ and Loos, 2007)

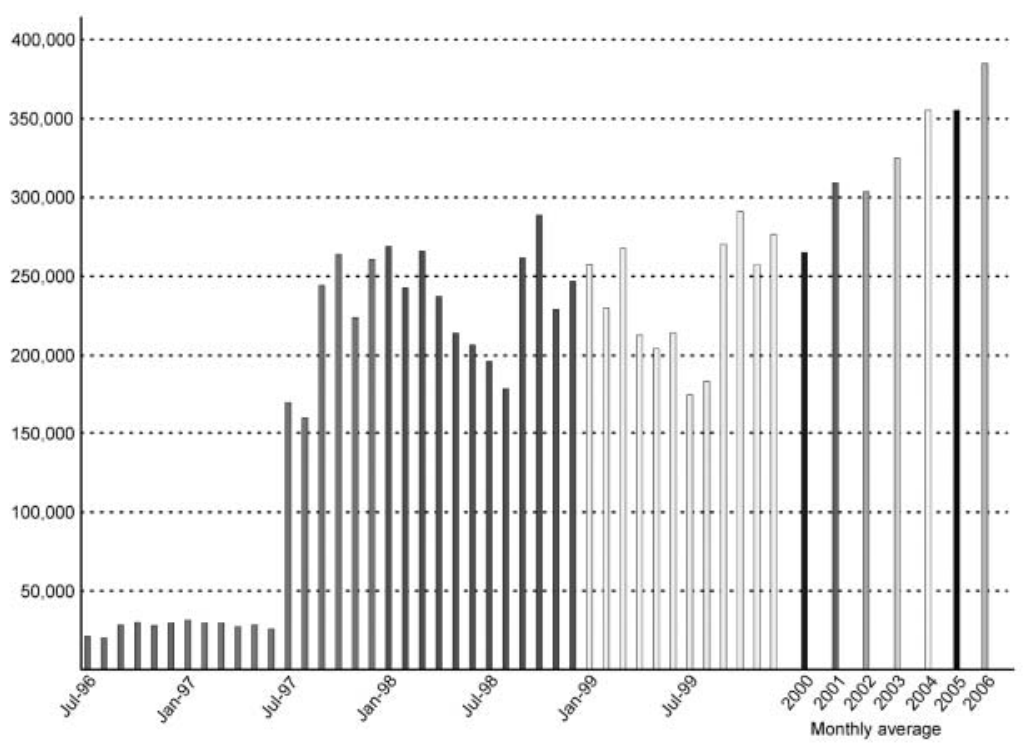

within a few months' (interview 30 June 2000). It is also said to have 'strengthen[ed] the social tissue' (Albrechts, 2004, p. 250) in Hasselt because citizens, especially the elderly, meet and chat on the bus. By 2003, Lijsweik began to acknowledge that 'the free public transport [also] has some negative side effects' (email 10 February 2003), in particular the massive onrush at peak times. He and others are more and more inclined 'to keep the buses free outside rush hours, but let the passengers pay a small fee (e.g. €0.5) during the peak hour' (Ibid.).

Public opinion of the Green Boulevard is overwhelmingly positive: 78 per cent of 453 Hasseltians surveyed (Jacobs, 1996c, p. 11) are in favour of it but again, it is not perfect: 'People just don't use it' is Lieshout's assessment (interview 27 November 2001) of the tree-lined pedestrian lane in its middle. Also Lijsweik, who was professionally involved in the planning process, admits this phenomenon. He explains that the cobblestone parking lane between the inner pavement and the pedestrian lane effectively functions as a barrier, even though the traffic there is very slow and there is very little of it. This has also hampered the establishment of bars, cafés and restaurants with decks and porches which was anticipated. A doubleedged effect is the creation of 'spatial value added' (Verdee, n.d., p. 18) for Hasselt's housing market. Now, living along the boulevard is much more pleasant which triggers investment and increases the rents of properties there.

Anyone interested in the realpolitik of urban policy will also find the assessment noteworthy that 'this project was Hasselt's best ever city marketing project', as an official publication of the Flemish Department for Transport put it (MVGWV, 2001, p. 29). In the first year, 98 articles were published in the Belgian press and at least 28 articles in foreign publications (Hasselt: Stadt, 1998, p. 22), while a range of television stations, from the local broadcasting company to CNN (MVGWV, 2001, p. 29), disseminated information about the 'miracle of Hasselt' (Hasselt: Stadt, 1998, p. 22). Approximately 120 study visits were made to the city in the year after the free buses were launched (Anon., 1999, p. 9) and the project even helped to boost tourism in Hasselt (Peperman, interview 26 June 2000). That much attention in turn makes Hasseltians 'very proud of 
their buses' (Mulders, interview 30 June 2000) and sparked 'a will to live, a dynamic, and a strongly improved image of the city compared to 10 years ago, when Hasselt was a dead city' (Lieben-Claes, interview 29 June 2000).

While initially, Hasselt's shopkeepers were rather sceptical, especially about the new parking policy, many of them now share the view of Ady Franssen, the chairman of the local retailers' association, who praises the free buses as a 'direct hit for the publicity of our city' (cited in Jacobs, 1997 c, p. 1). This experience convinced the retailers' association to pay for a substantial expansion in the bus service during the Christmas shopping period (Jacobs, 1997d, p. 14). The Green Boulevard and the oneway direction on it are not equally popular among shopkeepers. Meulendijk even reports that 'all the retailers in the city are against it' (interview 27 November 2001). In my own informal conversations with several shopkeepers, however, I sensed only sporadic complaints. While Lijsweik has heard some disapproving voices too, he adds: 'You will never find a shopkeeper that is happy with things' (interview 27 November 2001). An interesting indicator is the result of a survey conducted among major national chains in Belgium. It revealed that Hasselt is the second most desired city in which to open a shop in all of Belgium. The organizer of this survey, Geert de Ras, elaborates: 'It is remarkable that the renovation of the city centre and the mobility-enhancements clearly play a role' (cited in Jacobs, 2002).

It seems fair, then, to say that the overall assessment is positive - certainly compared to the previous situation - and that Hasselt deserves the status, not necessarily as universal best practice model, but at least as source of inspiration.

\section{Interpretation: Closing the Total Chain of Experiential Needs}

With reference to the prevailing structure of the sustainability discourse mentioned in the introduction it makes sense to argue that Hasselt's mobility policy relies neither on social nor on technical fixes alone. Instead, socially-desired behaviours are made convenient. This is not identical to social engineering because all alternative forms of social practices are still possible. In other words, it is not about making undesired behaviours impossible but about enabling and facilitating desired behaviours. This idea is, of course, not new. Environmental psychologists have long argued that the material context co-shapes behaviours. Osmond (1957), for example, demonstrated how physical settings can discourage or encourage social interaction in a psychiatric ward. Similar insights about the behaviour-steering effects of the physical surroundings are employed in every store to maximize purchases. Also the urban environment mediates social conditions, relationships and behaviours. The concept of Crime Prevention Through Environmental Design (Newman, 1973), for example, tries to harness such mechanisms and so do the designers of 'self-explaining streets' (Schmitt, 2004) who use cobblestones, speed bumps, street narrowing and other features to prevent motorists from speeding. In short, the urban environment in the widest possible sense is among the key factors that condition, enforce, restrict, suggest, facilitate and solidify the way daily lives are acted out. This is not to adopt environmental determinism blindly but to acknowledge that, although we are free to choose otherwise, our surroundings exert a pull on social practices.

Scholars of Science and Technology Studies (STS) call the characteristics of artefacts that influence social or behavioural reactions their 'programmes of action' (Latour, 2000) or 'scripts' (Akrich, 1992). Environmental psychologists mean very similar phenomena when they talk about 'affordances' (Gibson, 1977) and I typically refer to these socio-active features as the overt or hidden 'agendas' of artefacts. The car-friendly city, for example, which colonized the minds of planners and architects for decades certainly had a socio- 
active agenda built into it - and a hugely successful one at that. Most cyclists have experienced what it means to act against this agenda. It is like swimming against the current and often requires almost heroic choices. It is worth noticing that no such thing exists as an artefact without any agenda whatsoever. Accordingly, the morphology, layout and design of a particular city always makes certain behaviours more and others less convenient - some of these effects are deliberate, others unintentional. If we cannot avoid building socio-active agendas into the urban physical fabric, maybe we can find ways to harness this phenomenon in a positive way - as Hasselt did.

But of course, it is not simply possible to turn every city into a clone of Hasselt. Apart from the general undesirability of such a proposal, it would be naïve to assume that our built environment can be shaped at will and over night. Questions of power, vested interests, investment cycles, path dependencies, social fairness and many more make the design of every artefact - and in particular of an artefact the size of a city - an extremely complex venture (see Valderrama and Jørgensen, this issue). STS, and in particular its strand known as SCOT (the Social Construction of Technology) (Pinch and Bijker, 1984), also offers conceptual tools to understand this side of the equation. An exclusive focus on either of these two causal directions - the social shaping of the built environment or the shaping of the social by the built environment - would amount to 'watching half the court during a tennis game' (Latour, 1992, p. 247). It makes much more sense to view the relationship between the social and the technical as recursive, bidirectional and iterative. Neither the human nor the non-human thus deserves the status of an unmoved mover, an a priori explanans, or an 'exogenous variable' (Bijker and Law, 1992, p. 5). STS operates on exactly this ontological basis. It deliberately blurs the distinction between human and non-human actors (Latour, 1992) and thus provides a very useful theoretical, stereoscopic framework for understanding mobility as a socio-technical system.

In practical terms, the development and implementation of an appropriate physical frame that can facilitate certain sustainable mobility behaviours requires political savvy, funding opportunities, reliable allies and a range of other adjuvant parameters. What certainly helped in Hasselt was the "wind of change' blowing through the city after a Socialist-Green coalition under a young and reportedly 'charismatic' mayor (Albrechts, 2004, p. 249) broke the several decades long hegemony of the Conservative party in the local elections of 1994. A fortunate factor was also the Mobiliteitsconvenant, a Flemish funding instrument supporting the selfhelp efforts of cities to tackle their mobility problems. The new city government also managed to draw on some other sources of financial support but left most of the institutional and organizational frameworks it inherited intact (for more details see Brand, 2005a; Albrechts, 2004). Such beneficial conditions are necessary but neither sufficient nor easy to fabricate and shall not be the focus of this paper.

A complementary, equally insufficient but also equally necessary condition is easier to meet - although with hard work: an extremely detailed level of understanding of what I propose to call people's total chains of experiential needs, a kind of knowledge whose importance de Certeau (1984) emphasized in his poignantly titled book The Practice of Everyday Life. I tend to argue that this is actually the main lesson to be learned from Hasselt, not the details of the individual measures per se. It is their careful and systemic integration that makes this project so remarkable and, in my view, successful. Hasselt's public relations officer presents such an example of the interlacing of traffic guidance, street design, parking policy and public transport:

We would like that the people drive to designated parking garages via the main access roads... 
From there they should be able to reach their destination hassle-free with the bus. (cited in Jacobs, 1997a, p. 13).

To ensure the attractiveness of this desired behaviour, pull factors are combined with push factors: the designated parking garages are guarded and optimally connected to the bus system, whereas parking spaces in central residential areas are relatively pricey. In a similar fashion, visitors coming to Hasselt by train are not only provided with clean, free and frequent buses and information about their schedules, but also with the possibility to rent bicycles, to store their shopping goods at a safe place, to stroll under shaded parkways undisturbed by cars, to sit and relax on flat-surfaced Verkeerspaaltjes, to use clean public restrooms at a bus interchange and to enjoy a hot snack while waiting for the return train. Another exemplary thread of dovetailed measures is the combination of bicycle lanes, bonuses for bicycling commuters, guarded bicycle shelters with sturdy racks, and showers and cloak rooms for employees who cycle to work. Only this combination of measures can make the whole day experience of a cycling commuter truly hassle free.

In conceptual and analytical terms, this approach seems to work because it leaves no broken links in the total chain of experiential needs. The installation of showers in public buildings, for example, demonstrates this concept quite nicely. Without them, even the construction of bicycle lanes and shelters is unlikely to have a big impact because those who may consider commuting by bicycle will still not be prepared to cover their sweaty bodies with their office attire (on related issues see Cox, this issue). A missing shower could be the bottleneck that prevents desired behaviours from being acted out. The chain metaphor is especially well suited to emphasize this point because it highlights that the weakest element determines the strength of a whole system. This underlines the necessity to develop a coherent strategy with a simultaneous focus on all relevant social and technical issues and not to invest in few, but isolated, spectacular measures. This is also a textbook example of synergy because the combined effect of wellintegrated measures is greater than the sum of their individual effects. Robinson shares this view and argues for an approach 'that focuses on the connections among fields as much as on the contents of those fields; that involves the development of new concepts, methods and tools that ... create synergy, not just summation' (Robinson, 2004, p. 378). Closely related to this statement is the recommendation to focus on systemic transition that 'consists of a set of connected changes in technology, the economy, institutions, behaviour, culture, ecology and belief systems that reinforce each other' (Kemp and Rotmans, 2005, p. 4).

In other words, for successful system change a whole range of strings must pull together in a simultaneous and co-ordinated way. This systems view also demonstrates that there is potentially more than one total chain of experiential needs linking different elements of people's social practices: we can either install showers or change people's attitude towards hygiene. We can either clear bicycle lanes more regularly of dirt and shards that tend to accumulate on them or we can promote bicycle tyres with kevlar ${ }^{\circledR}$ linings. Either way, it is necessary to leave no unreasonable 'gap' (Jelsma, 2005) in the experience of a cyclist - or a bus user, a pedestrian or any other urban 'user' for that matter.

A lack of such experiential understanding typically causes certain links in the chain to be overlooked. It may well be possible to bridge a few small missing links through education, persuasion, or tax incentives which can make someone endure a sub-optimal condition and still behave in a desired way. For example, the lack of a bicycle lane along quiet stretches of my commuting route would not keep me from cycling to work. If the missing links get too big, too important, however, no awareness campaign will ever bridge such a gap. In such 
cases, people will simply reject adoption of the rest of the chain or, in Latour's words, they might develop anti-programmes, that is, all kinds of attempts 'to annul, destroy, subvert, circumvent a program of action' (Latour, 2000, p. 7).

\section{Participation as Source of Information and Commitment}

No one can possibly know all chains of all mobility-related experiential needs of all social groups. Those who shape our built environment therefore should make every effort to acquire this understanding. A promising way to do this seems to be direct engagement with future users through participatory forms of design. This would not only ensure ownership and buy-in of the participants but also, and maybe even more importantly, provide the required insights into the minutiae of people's everyday needs. It would help to identify those chains that can be completed most effectively and most efficiently.

There is no way for design professionals to know where interventions are most effective because there is no one single correct answer. Most probably, the answers are emergent in the sense that they come into existence in the process of debate and discussion. Although this latter claim is yet to be tested empirically, we can be close to certain that hardly any designer or engineer knows which chain to tackle and by what means - regardless of whether the most productive answers are pre-existing or emergent. The literature on user innovators provides more than sufficient support for this position (e.g. Brand, 2005b; Franke and Shah, 2003; Hoogma et al., 2002; Jelsma, 2005; Kuhn and Winograd, 1996; Ornetzeder, 2002; Rohracher, 2005; Schot, 2002; Stewart and Williams, 2005; Von Hippel, 2001).

Participatory design might trigger and harness yet another mechanism which seems highly plausible but has yet to be tested through systematic, empirical investigation.
It might help to overcome a 'first mover disadvantage' (Brand, 2005b), which describes a situation in which a considerable part of the population is latently willing to behave in a certain way - but only if there is a guarantee that 'the others' will do it too. This sociopsychological phenomenon is actually a quite rational mechanism against the exploitation by free-riders (Taylor, 1976). Unfortunately, it can grow to a full blown social dilemma and reticent sclerosis. Unless those who are, in principle, willing to change their behaviour under the condition that they are not the only ones, articulate this conditional willingness, nobody will move. Participatory design processes seem suitable to provide platforms for this articulation to happen. Sclove (1992) emphasizes the same point by arguing that the participation renders transparent the social contingency of socio-technical systems and thus elicits critical reflection on social circumstances, preferences and needs.

The stalemate caused by a first mover dilemma can also run along a different axis: between users and providers of infrastructures. It is certainly not too contrived to imagine a situation in which users of the built environment think 'we won't commute by bike as long as there are no showers' while the supply side argues 'we won't provide showers because hardly any one commutes by bike any way.' Participatory design processes - if they are well managed - seem to be potentially very effective escape valves out of such vicious circles in which users and providers often shift first-mover responsibility back and forth between them. Participation allows users and providers to learn about the respective other's concerns, constraints, possibilities and conditional willingness to change. Schot and Rip (1996) refer to this dynamic as 'second-order learning' which connotes a process whereby 'the supply and the demand side articulate and question their current preferences in search of a new "fit"' (Brand and Gaffikin, forthcoming). Such a process is possible because preferences are not fixed (Fainstein, 
2000); they are malleable because they are contingent upon circumstances, including the preferences of others.

It has to be noted, however, that even the most candid discussions among users and between users and providers may not eliminate all inconveniences. After all, compromises with other street users will have to be made even in the most bicycle-friendly city. For example, it may not be possible for technical or financial reasons to build an underpass under a large intersection. To cross it on a bicycle may thus remain unpleasant - no matter how healthy, safe, fast, cheap and convenient the rest of the journey might be. But the explicit awareness of one's stated complicity with other cyclists and even with, say, the city council, might help to bridge that gap in the otherwise complete chain of experiential needs. As mentioned above, it has not yet been empirically tested whether the interpretation around the issue of a firstmover disadvantage is shared by the people and officials in Hasselt. Such studies - in Hasselt or elsewhere - would enormously enrich the understanding of the sociotechnical dynamics of sustainable mobility systems.

What has been studied is Hasselt's actual commitment to participatory design approaches. It did, indeed, employ a number of participatory strategies in the development of its new mobility policy. A detailed description of these approaches is beyond the scope of this paper but is available in Brand (2005a). What should be mentioned here, however, is the fact that after its election victory in 1994, the Socialist-Green coalition in the city parliament began tackling the mobility problem with a participatory inventory of the most problematic traffic points, conducted through fifteen public hearings. ${ }^{3}$ This step was considered 'completely impossible without the contribution of ... the citizenry' (Van Moerkerke, 1997, p. 7) and Lijsweik remembers it as 'a very interesting idea to let the people have something to say about the traffic problems in their surroundings'
(Lijsweik, email 10 February 2003). The search for solutions was conducted under the explicit exclusion of the citizenry, because this is the business of planners, traffic experts and designers who are authorized in this regard' (Van Moerkerke, 1997, p. 8). This phase was clearly no exemplar for the formal participation of future users.

With more citizen input, the failure of the pedestrian lane might have been averted, because citizens could have foreseen that it was less attractive to them than anticipated by professional planners. The plan for the redesign of the inner ring road was then presented to the public through the regional press, information boards, the city newspaper, a mock-up model displayed in the City Hall, public hearings, an information bus and mailings to neighbourhoods, retailers, and service providers (Anon., 1999, p. 5; Van Moerkerke, 1997, p. 16; MVGWV, 2001, p. 21). All citizens, and especially those living close to the inner ring road, were invited to voice their opinion on the plan, which led at least to some detail changes. Despite this serious effort to inform the public, it still qualifies as 'end-of-the-pipe input', although I do not share the impression that the project was 'pushed through' (anonymous Hasselt shopkeeper, personal communication 3 December 2001).

There are obviously differing opinions on Mayor Stevaert's leadership style (for a positive assessment see Albrechts, 2004), but it is also obvious that Hasselt's decision-makers could have pursued an even more proactive approach in encouraging citizens to add their input in the development of solutions. Stevaert himself refutes the allegation that he made decisions detached from people's real desires; quite the contrary, he claims to be an 'expert in people' (interview 6 December 2001). Indeed, no single interlocutor denied Stevaert's affability and empathy, which people say stems from his experience as the owner of several coffee bars. There, the uncontested account goes, 'he learned to listen to people and to know what's going 
on in their minds' (Lijsweik, interview 27 November 2001; similarly Mulders, interview 30 June 2000). In short, almost everyone agrees that the involvement of the public did not quite reach the limits of what is possible if participation is taken seriously. However, there is very little disagreement on the assessment that the participatory elements of the process went considerably beyond what could have been expected from the previous Conservative government and maybe even beyond best Flemish practice.

Does this fuel the arguments of those impatient sustainability enthusiasts who 'expect enlightened dictators to bite the bullet of technological reform ... if a greedy populace shirks its duty'? (Feenberg, 1995, p. 12). Further research is required to investigate whether knowledge of benign and enlightened leaders about their subordinates' experiential needs can substitute for participatory design processes. If it can, it would seriously question the relevance and necessity of participation as a means to learn about these needs. It would not, however, undermine the argument that their thorough understanding is a precondition for a successful synchronization of social and technical change, which, it seems, has great potential for making serious headway towards a more sustainable world.

\section{Conclusion}

Social and technical change can and should be aligned or synchronized. Hasselt managed to achieve this to a considerable degree. Its citizens did change their behaviour - but not as a result of a resounding awareness campaign. And its technical infrastructure did change too - but not as an attempt to make any form of compliance by untrusted citizens obsolete. Hasselt's mobility policy does not resist but embraces the messy and complicated fact that 'social and technical change come together, as a package' (Bijker and Law, 1992, p. 11). In other words, the physical and social aspects of urban life are seen and treated as part of one and the same system. Unfortunately, many academics still have difficulties in employing this perspective. Deeply ingrained disciplinary reflexes and structural incentives are not very conducive to such a systemic view and keep us from looking beyond our own doorstep. Latour (2000, pp. 9-10) makes this point quite drastically, but rightly so: 'sociologists, like technologists, enemy brothers, ... do not manage to end ... their fratricidal war, a war that prevents us from understanding the world in which we live'.

But there is good news too. The survival strategies of urban practitioners often do not grant them the luxury to pursue ideological purity. This disregard for artificial boundaries can be an excellent stimulus for co-evolutionary ideas once their seed is sown in practitioners' minds. But even academics have begun to prove Latour's scepticism wrong by developing tools which can facilitate co-evolutionary processes. Strategic Niche Management (Hoogma et al., 2002) or Constructive Technology Assessment (Rip et al., 1995) are existing examples and others, such as the Co-Evolution Audit, are currently being developed. Those who design our built environment and urban artefacts should adopt and further develop these approaches in order to make the chain of the urban dwellers' experiential needs as complete as possible in order to facilitate truly realistic alternatives to the prevailing unsustainable mobility practices.

\section{NOTES}

1. Genk, with its slightly smaller population, is the industrial hub of Limburg and thus does not greatly challenge Hasselt's pole position in the service, retail and education sector.

2. Before July 1997 the provincial bus company deployed eight buses throughout Hasselt; by 2006, this number has grown to forty-five. The number of journeys per day has equally increased from eighty-four to 794 in the same period (Loos, 2007). 
3. This tradition of participatory problem definition is being continued. In 2005/2006, for example, the city conducted fifteen citizen meetings throughout Hasselt to identify problematic traffic spots (Stad Hasselt, 2007a).

\section{REFERENCES}

Akrich, Madeleine (1992) The description of technical objects, in Bijker, W.E. and Law, J. (eds.) Shaping Technology/Building Society: Studies in Sociotechnical Change. Cambridge, MA: MIT Press, pp. 205-224.

Albrechts, Louis (2004) Creativity as a driver for change. Planning Theory, 4(3), pp. 247-269.

Anable, Jillian, Lane, Ben and Kelay, Tanika (2006) A Review of Public Attitudes to Climate Change and Transport Behaviour - Summary Report for The Department of Transport. Available at <www.dft.gov.uk/162259/163944/A_review_ of_public_attitude1.pdf $>$. Accessed 13 July 2007.

Anon. (1999) Mobility with an eye to the environment: Hasselt, an example for Europe. Unpublished manuscript by unknown author. Document available from the author.

BBC (2006) Bush in a Lighter Shade of Green. News article on BBC online on February 1 2006. Available at <http://news.bbc.co.uk/1/ hi/world/americas/4669870.stm>. Accessed 13 July 2007.

Bijker, Wiebe and Law, John (1992) General introduction, in Bijker, W.E. and Law, J. (eds.) Shaping Technology/Building Society: Studies in Sociotechnical Change. Cambridge, MA: MIT Press, pp. 1-14.

Brand, Ralf (2005a) Synchronizing Science and Technology with Human Behaviour. London: Earthscan.

Brand, R. (2005b) The citizen-innovator. The Innovation Journal, 10(1), pp. 9-19. Available at <www.innovation.cc/peer-reviewed/ralfbrand.pdf $>$. Accessed 17 July 2007.

Brand, Ralf and Gaffikin, Frank (2007) Collaborative planning in an uncollaborative world. Planning Theory, 6(3) pp. 282-313.

de Certeau, Michel (1984) The Practice of Everyday Life, trans. Steven Rendall. Berkeley: University of California Press.

Fainstein, Susan (2000) New directions in planning theory. Urban Affairs Review, 35(4), pp. 451-478.

Feenberg, Andrew (1995) Subversive rationalization: technology, power, and democracy, in
Feenberg, A. (ed.) Technology and the Politics of Knowledge. Bloomington: Indiana University Press, pp. 3-22.

Franke, Nikolaus and Shah, Sonali K. (2003) How communities support innovative activities: An exploration of assistance and sharing among end-users. Research Policy, 32, pp. 157-178.

Gibson, James (1977) The theory of affordances, in Shaw, R. and Bransford, J. (eds.) Perceiving, Acting, and Knowing. Hillsdale, NJ: Lawrence Erlbaum Associates.

Hajer, Maarten (1996) Politics on the move: the democratic control of the design of sustainable technologies. Knowledge and Policy, 8(4), pp. 26-39.

Hasselt: Stadt ohne Fahrschein. (Busverkehr zum Nulltarif) (1998) [Hasselt: City without tickets]. Unpublished document, available from the author.

Hoogma, Reemco, Kemp, Rene, Schot, Johan and Truffer, Bernhard (2002) Experimenting for Sustainable Transport - The Approach of Strategic Niche Management. London: Spon Press.

Jacobs, D. (1996a) Tolerant optreden politie zorgt voor extra last (The tolerant demeanour of the police creates additional problems). Het Belang van Limburg, 5 June, p. 13.

Jacobs, D. (1996b) Met je winkelkar heel de stad door (With the shopping trolley through the whole city). Het Belang van Limburg, 16 November, p. 9.

Jacobs, D. (1996c). Romain Onkelinx is de bekendste schepen (Romain Onkelinx is the best known alderman). Het Belang van Limburg, 26 November, p. 11.

Jacobs, D. (1997a) Het prille succes van de Hasseltse boulevardpendel Belangrijke waardemeter (The early success of Hasselt's boulevard shuttle 'important indicator'). Het Belang van Limburg, 12 March, p. 13.

Jacobs, D. (1997b) Hasselts stadsnet gratis tot 2000 (Hasselt's city net free of charge until 2000). Het Belang van Limburg, 1 August, pp. 1, 17.

Jacobs, D. (1997c) Meer taxi's na 50 dagen gratis bus (More taxis after 50 days of free buses). Het Belang van Limburg, 21 August, pp. 1, 10.

Jacobs, D. (1997d) Al een miljoen reizigers voor Hasselts stadsnet (Already one million users of Hasselt's city net). Het Belang van Limburg, 19 December, p. 14.

Jacobs, D. (2001) Gratis bussen in Hasselt tot 2006 (Free buses in Hasselt until 2006). Het Belang van Limburg, 20 November, p. 1. 
Jacobs, D. (2002) 52 winkelketens zoeken plek in centrum Hasselt (52 chains search for a location in the centre of Hasselt). Het Belang van Limburg, 25 July, page unknown.

Jelsma, Jaap (2005) Bridging gaps between technology and behaviour: a heuristic exercise in the field of energy efficiency in households, in Rohracher, H. (ed.) User involvement in innovation processes - Strategies and limitations from a socio-technical perspective. Munich, Vienna: Profil: pp. 73-106.

Jepson, Edward (2004) Human nature and sustainable development - a strategic challenge for planners. Journal of Planning Literature, 19(1), pp. 3-15.

Job D. A. (1995) Geography and Environmental Education - an exploration of perspectives and strategies, in Kent W., Lambert D., Naish M. and Slater F. (eds.) Geography in Education. Cambridge: Cambridge University Press.

Kemp, Rene and Rotmans, Jan (2005) The management of the co-evolution of technical, environmental and social systems, in Weber M. and Hemmelskamp, J. (eds.) Towards Environmental Innovation Systems. Heidelberg, New York: Springer, pp. 33-55.

Kuhn, Sara and Winograd, Terry (1996) Profile 14 - participatory design, in: Winograd, T. (ed.) Bringing Design to Software. New York: AddisonWesley, pp. 290-294.

Lambrechts, Daniel (2000a) Hasselt-Aantaal busgebruikers: Vroeger en nu -97-98-99-00.doc (Hasselt - Ratio of bus users: Previously and now -97-98 -99-00). [Data file transmitted via email].

Lambrechts, D. (2000b). Hasselt-Aaantal busgebruikers, vroeger en nu: Stadsnet en regionaal net.xls (Hasselt - Ratio of bus users, previously and now: City net and regional net). [Data file transmitted via email].

Lambrechts, Daniel (2001) Duurzaam Mobiliteitsbeleid op twee Sporen (Sustainable mobility policy on two tracks). Hasselt: Unknown publisher.

Latour, Bruno (1992) Where are the missing masses? The sociology of a few mundane artifacts, in Bijker, W.E. and Law, J. (eds.) Shaping Technology/Building Society: Studies in Sociotechnical Change. Cambridge, MA: MIT Press, pp. 225-264.

Latour, Bruno (2000) The Berlin key or how to do words with things, in Graves-Brown, P.M. (ed.) Matter, Materiality and Modern Culture. London: Routledge, pp. 10-21.

Loos, Sonja (2007) Cijfers-stadsnet-Hasselt- v20070621.doc (Figures-city net-Hasselt). [Data file transmitted via email].

MVGWV (Ministerie van de Vlaamse Gemeenschap, Afdeling Wegen en Verkeer Limburg) (2001) De Groene Boulevard in Hasselt Vlaanderen. Een duurzame oplossing voor mobiliteit in de stad (The Green Boulevard in Hasselt - Flanders. A sustainable solution for mobility in the city). Brussels: Vlaamse Gemeenschap.

Newman, Oscar (1973) Defensible Space. London: Architectural Press.

O'Riordan, Tim (1989) The challenge for environmentalism, in Peet, R. and Thrift, N. (eds) New Models in Geography. London: Unwin Hyman, pp. 77-102.

Ornetzeder, Michael (2002) Old technology and social innovations: Inside the Austrian successstory on solar water heaters, in Jamison, A. and Rohracher, H. (eds.) Technology Studies and Sustainable Development. Munich,Vienna: Profil, pp. 365-382.

Osmond, Humphrey (1957) A review of the clinical effects of psychotomimetic agents. Annals of the New York Academy of Sciences, 66, pp. 418-434.

Pinch, Trevor and Bijker, Wiebe (1984) The social construction of facts and artefacts: or how the sociology of science and the sociology of technology might benefit each other. Social Studies of Science, 14, pp. 388-441.

Quintiens, L. E. (n.d.). Groene Boulevard wandeling Hasselt (A walk along the Green Boulevard in Hasselt). Unpublished document, available from the author.

Ravetz, Joe (2001) City Region 2020 - Integrated Planning for a Sustainable Environment. London: Earthscan.

Rip, Arie, Misa, Thomas and Schot, Johan (eds.) (1995) Managing Technology in Society - The Approach of Constructive Technology Assessment. London: Pinter.

Robinson, John (2004) Squaring the circle? Some thoughts on the idea of sustainable development. Ecological Economics, 48, pp. 369-384.

Rohracher, Harald (ed.) (2005) User involvement in innovation processes - Strategies and Limitations from a Socio-technical Perspective. Munich, Vienna: Profil.

Schmitt, C. (2004) Abgeblitzt! [Rejected!] Die Zeit, 8 January, p. 56.

Schot, Johan (2002) Towards new forms of participatory technology development, in Jamison, A. and Rohracher, H. (eds.) Technology 
Studies and Sustainable Development. Munich, Vienna: Profil, pp. 41-64.

Schot, Johan and Rip, Arie (1996) The past and future of constructive technology assessment. Technological Forecasting and Social Change, 54(2-3) pp. 251-268.

Sclove, Richard (1992) The nuts and bolts of democracy: democratic theory and technological design, in Winner, L. (ed.) Democracy in a Technological Society, Dordrecht: Kluwer Academic Publishers, pp. 139-157.

Stadt Hasselt (2007a) Verkeersveiligheid (Traffic safety). Municipal website. Available at $<$ http: / / www.hasselt.be/content/main/home_ content.php?ID=365>. Accessed 25 July 2007.

Stad Hasselt (2007b) Voetgangers ( Pedestrians). Municipal website. Available at <http://www. hasselt.be / content/main / home content.php?ID=179>. Accessed 25 July 2007.

Stern, Nicholas (2007) The Economics of Climate Change - The Stern Review. Cambridge: Cambridge University Press.

Stewart, James and Williams, Robert (2005) The wrong trousers? Beyond the design fallacy: social learning and the user, in Rohracher, $\mathrm{H}$. (ed.) User Involvement in Innovation Processes - Strategies and Limitations from a Socio-technical Perspective. Munich \& Vienna: Profil, pp. 39-72.

Stuurgroep Hasselt Levendig Stadscentrum (1994). Hasselt levendig stadscentrum (Hasselt lively city centre). Study report with limited circulation. Hasselt: Self-published.

Taylor, Michael (1976) Anarchy and Cooperation. London: John Wiley \& Sons.

Thayer, Robert L. Jr. (1994) Gray World, Green Heart - Technology, Nature and the Sustainable Landscape. New York: Wiley.

van Moerkerke, Bart (1997) Hasselt - Een mobiliteitsbeleid in ontwikkeling (Hasselt - A mobility policy in the making), in Het Mobiliteitshandboek. Mechelen: Kluwer, pp. Hasselt/1- Hasselt/18.

Verdee, E. (n.d.) Groene Boulevard - Stedelijke Analyse Hasselt (Green Boulevard - Urban Analysis Hasselt).Unpublished manuscript - available from the author.

Von Hippel, Eric (2001) User toolkits for innovation. Journal of Product Innovation Management, 18, pp. 247-257. 